\title{
Zinc Finger Protein 224
}

National Cancer Institute

\section{Source}

National Cancer Institute. Zinc Finger Protein 224. NCI Thesaurus. Code C126565.

Zinc finger protein 224 (707 aa, $\sim 82 \mathrm{kDa}$ ) is encoded by the human ZNF224 gene. This protein plays a role in the regulation of gene transcription. 